DOI: https://doi.org/10.24127/ajpm.v10i2.3534

\title{
DESKRIPSI KEMAMPUAN PEMECAHAN MASALAH MATEMATIS DITINJAU DARI GENDER PADA MATERI BANGUN RUANG
}

\author{
Fitrianto Eko Subekti $^{1^{*}}$, Tri Krisdiani ${ }^{2}$ \\ ${ }^{1 *, 2}$ Pendidikan Matematika, Universitas Muhammadiyah Purwokerto, Indonesia \\ ${ }^{*}$ Corresponding author. Kalimanah, 53371,Purbalingga, Indonesia \\ E-mail: $\quad \underline{\text { efitrians@gmail.com }}^{\left.{ }^{*}\right)}$ \\ $\underline{\text { krisdianitri@gmail.com }}^{2)}$
}

Received 05 February 2021; Received in revised form 27 June 2021; Accepted 29 June 2021

\begin{abstract}
Abstrak
Penelitian ini bertujuan untuk mendeskripsikan kemampuan pemecahan masalah matematis ditinjau dari gender pada materi bangun ruang sisi datar. Jenis penelitian yang dilakukan adalah studi deskriptif kualitatif. Sampel diambil menggunakan teknik purposive sampling, yang terdiri dari tiga siswa laki-laki dan tiga siswa perempuan SMP N 2 Jatilawang. Pengambilan data menggunakan tes kemampuan pemecahan masalah matematis, wawancara, dan dokumentasi. Teknik analisis data dilakukan menggunakan tahapan, yaitu: reduksi data, penyajian data, dan penarikan kesimpulan. Uji validasi menggunakan triangulasi teknik, yaitu menggunakan tes, wawancara, dan dokumentasi. Hasil penelitian menunjukkan bahwa: siswa laki-laki cennderung dapat menyelesaikan permasalahan, hanya saja tidak melakukan cek kembali. Siswa perempuan cenderung menyelesaikan permasalahan sampai tahap mengecek kembali dengan benar. Perlu pembiasaan untuk mengecek kembali terhadap penyelesaian yang dilakukan agar setiap solusi yang diberikan terhindar dari kesalahan.
\end{abstract}

Kata kunci: Bangun ruang sisi datar; gender; pemecahan masalah matematis.

\begin{abstract}
This study describes the mathematical problem-solving capabilities reviewed from the gender on flat side space material. The type of research conducted is qualitative descriptive studies. Samples use purposive sampling techniques, consisting of three male students and three female SMP N 2 Jatilawang. Data retrieval uses mathematical problem-solving skills tests, interviews, and documentation. Data analysis techniques carry out using stages: data reduction, data presentation, and conclusion drawing. Validation tests use triangulation techniques, namely using tests, interviews, and documentation. The results showed that male students were able to solve problems and did not do a check back. Female students tend to solve problems until the stage of proper re-checking. It is necessary to habituate to double-check the solution so that each solution provided avoids mistakes.
\end{abstract}

Keywords: Flat side space material; gender; mathematical problem-solving.

This is an open access article under the Creative Commons Attribution 4.0 International License

\section{PENDAHULUAN}

Pemecahan masalah menjadi salah satu keterampilan yang dibutuhkan pada abad ke-21 (Ahdhianto et al., 2020; Jamaludin \& Hung, 2017). Melalui keterampilan ini diharapkan segala permasalahan kehidupan dapat teratasi. Pemecahan masalah menjadi tujuan inti pembelajaran matematika di sekolah dan menjadi keterampilan penting yang dibutuhkan dalam kehidupan sehari-hari (García et al., 2019; Hobri et al., 2020; Surya et al., 2017; Zhou et al., 2019), sehingga setiap siswa harus memilikinya (Ramdan et al., 2018). Pemecahan masalah menjadikan siswa dapat memahami matematika (Albay, 2019). Pemecahan masalah dalam 
pembelajaran matematika berfungsi untuk: a) sebagai langkah awal pengembangan ide dalam membangun pengetahuan baru dan keterampilan matematika (Yandari et al., 2019); b) memulai dan mempraktekan berbagai proses berpikir matematis (Nanna \& Pratiwi, 2020); dan c) meningkatkan kreatifitas (Khalid et al., 2020).

Namun kenyataannya kesulitan masih dijumpai dalam memahami dan memaknai informasi pada permasalahan yang diberikan, serta kesulitan dalam menentukan strategi pemecahan masalah yang sesuai. Kesulitan tersebut, menjadikan tidak terselesaikannya pemecahan masalah yang diinginkan.

Penelitian sebelumnya terkait pemecahan masalah menunjukan bahwa pada umumnya siswa mengalami kesulitan dalam merencanakan, menggunakan strategi yang tidak memadai dalam upaya untuk melakukan perhitungan (García et al., 2019). Permasalahan ini berakibat ketidaktepatan solusi yang diberikan. Kesulitan diawali dari ketidakmampuan dalam memahami masalah yang terjadi.

Permasalahan yang terjadi terkadang dalam penyelesaiannya dibutuhkan pengalaman-pengalaman yang dimiliki sebelumnya sebagai dasar untuk menyelesaikan permasalahan yang baru. Individu yang berhasil cenderung mampu menggunakan dan menghubungkan pengalaman sebelumnya dengan informasi yang tersedia (Chen \& Lin, 2019). Melalui pemecahan masalah memungkinkan individu menyelesaikan masalah baru yang dibangun di atas masalah sebelumnya atau masalah yang lebih kompleks (Rott, 2019).

Siswa laki-laki cenderung mengungguli siswa perempuan dalam matematika, sebaliknya siswa perempuan cenderung lebih unggul dalam membaca (Giofrè et al., 2020). Begitu juga kepercayaan diri laki-laki terhadap permasalahan matematika cenderung lebih tinggi dibandingkan siswa perempuan (Espinoza \& Taut, 2020). Perbedaan gender memberikan pengaruh terhadap kemampuan pemecahan masalah pada remaja (Mefoh et al., 2017).

Perbedaan karakteristik antara laki-laki dan perempuan diduga akan berakibat terjadinya perbedaan kemampuan pemecahan masalah matematis diantara keduanya. Perlu digali lebih dalam bagaimana kemampuan pemecahan masalah matematis siswa ditinjau dari gender. Adapun materi yang digunakan adalah materi bangun ruang sisi datar.

\section{METODE PENELITIAN}

Penelitian dilaksanakan di SMP Negeri 2 Jatilawang untuk mendapatkan gambaran lebih dalam kemampuan pemecahan masalah matematis ditinjau dari gender. Jenis penelitian yang dilakukan adalah deskriptif kualitatif dengan mengambil 6 responden, yaitu: 3 siswa laki-laki dan 3 siswa perempuan. Pengambilan sampel mempertimbangkan kemampuan komunikasi responden dari setiap kategori gender. Data kemampuan pemecahan masalah matematis diperoleh dari hasil tes, wawancara mendalam, dan dokumentasi. Tes kemampuan pemecahan masalah terdiri dari 2 butir soal essai pada materi bangun ruang sisi datar. Tes dan wawancara digunakan untuk mendapatkan informasi lebih dalam kemampuan pemecahan masalah matematis ditinjau dari gender. Teknik analisis data dilakukan dengan tahapan reduksi data, penyajian data dan penarikan kesimpulan. Reduksi data dilakukan dengan cara memilih dan 
DOI: https://doi.org/10.24127/ajpm.v10i2.3534

memfokuskan perhatian terhadap hasil tes dan wawancara yang diperoleh. Setelah direduksi, data disajikan dan disederhanakan untuk mempermudah dalam penarikan kesimpulan. Uji kredibilitas data menggunakan uji trianggulai teknik dengan membandingkan hasil tes dan wawancara yang telah dilakukan.

\section{HASIL DAN PEMBAHASAN}

Data kemampuan pemecahan masalah matematis diperoleh berdasarkan hasil tes dan wawancara mendalam. Pada setiap soal responden diminta menyelesaikan permasalahan dengan mengacu pada 4 tahapan penyelesaian masalah, yaitu: memahami masalah, menyusun strategi, mengaplikasikan strategi, dan merefleksi.

Untuk mempermudah dalam proses pendeskripsian data, responden laki-laki 1, 2, dan 3 secara berturut-turut diberikan simbol PA1, PA2, dan PA3. Sedangkan responden perempuan 1, 2, dan 3 secara berturut-turut diberikan simbol PI1, PI2, dan PI3.

Pada soal nomor 1, responden dituntut untuk dapat menentukan volume menara yang berbentuk gabungan antara prisma dan limas, jika diketahui tinggi menara $13 \mathrm{~m}$, alas menara berbentuk persegi panjang yang memiliki panjang dua kali lebarnya, keliling alas menara $18 \mathrm{~m}$, dan tinggi prisma $7 \mathrm{~m}$. Berikut jawaban dan deskripsi dari setiap responden.

\section{Deskripsi kemampuan pemecahan masalah matematis responden laki-laki untuk soal nomor 1}

Gambar 1 merupakan hasil pekerjaan PA1 terkait permasalahan volume gabungan prisma dan limas. Responden menggunakan 4 langkah penyelesaian.

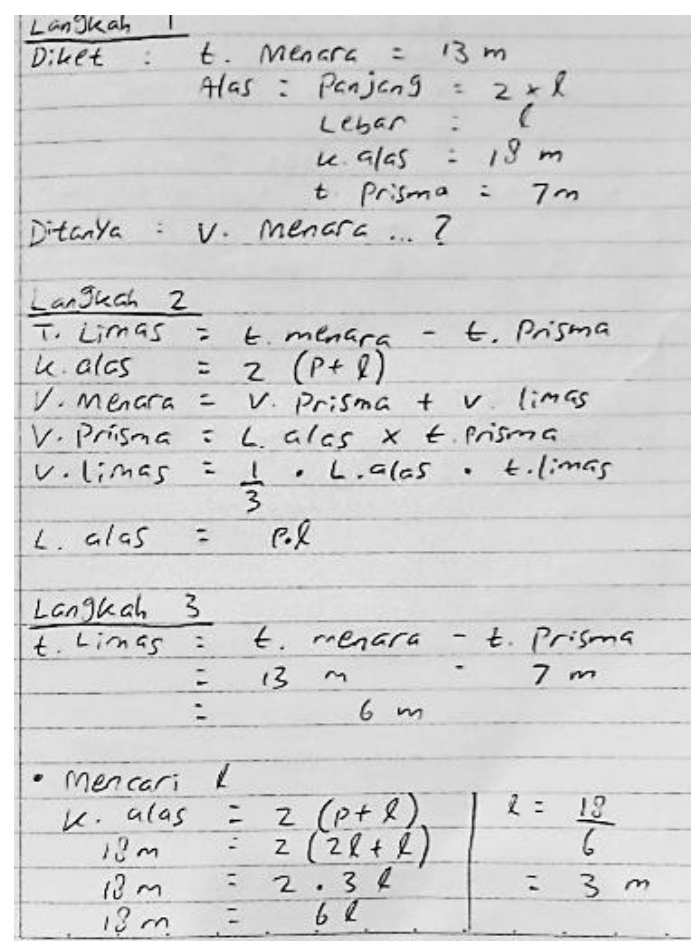

Gambar 1. Jawaban responden PA 1 pada soal nomor 1

Pada tahap memahami masalah responden PA1 menuliskan unsur-unsur yang diketahui, yaitu: tinggi menara, ukuran alas (panjang dan lebar), keliling alas serta tinggi prisma dengan benar seperti pada Gambar 1. Penulisan unsur yang ditanyakan sudah sesuai, hanya saja menggunakan tanda tanya. Selanjutnya PA1 melakukan tahap menyusun strategi dengan menuliskan setiap rumus yang dibutuhkan dalam menyelesaikan masalah tersebut. Rumus yang dituliskan yaitu: keliling alas, volume menara, volume prisma, volume limas, serta luas alas. Pada tahap mengaplikasikan strategi, PA1 terlebih dahulu menghitung tinggi limas, yaitu tinggi menara dikurangi tinggi prisma. Panjang dan lebar alas menara (persegi panjang) ditentukan menggunakan keliling yang sudah diketahui. Setelah mengetahui panjang dan lebar alas, PA1 menghitung luas alas yang akan digunakan untuk mencari volume 
prisma dan limas. Untuk mencari volume menara, PA1 menjumlahkan volume prisma dan limas seperti pada Gambar 2. Responden menuliskan langkah 4 dengan menjumlahkan volume prisma dan limas. Selain itu, responden tidak melakukan refleksi kembali.

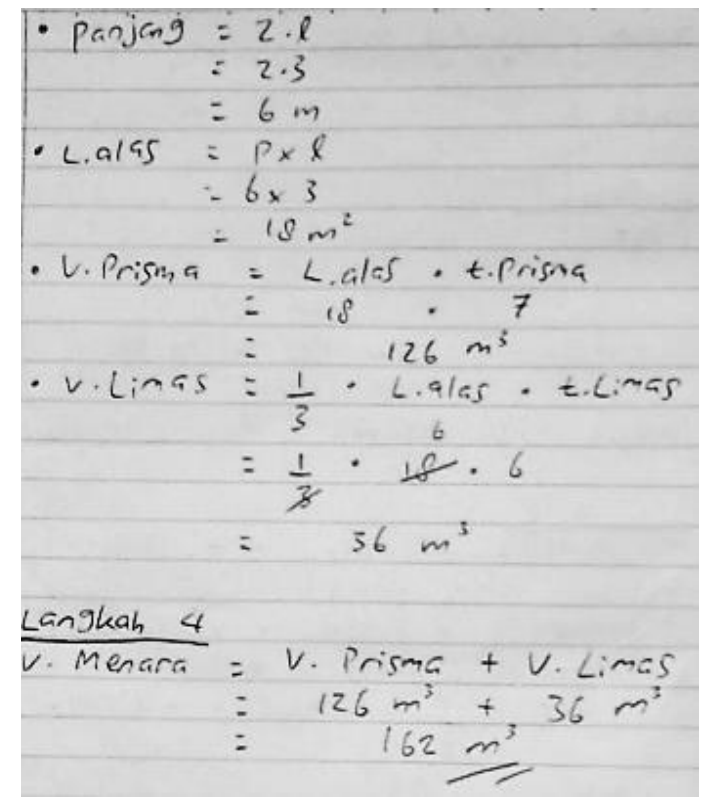

Gambar 2 Lanjutan jawaban soal nomor 1 responden PA1

Pada saat wawancara dengan responden PA1 mengatakan bahwa telah memeriksa kembali jawaban yang diperoleh, hanya saja tidak dituliskan dalam lembar jawab. Responden PA1 menghitung ulang berdasarkan rumus yang tersedia pada lembar coret-coretan. Responden PA1 terbiasa mengerjakan soal-soal yang diberikan guru tanpa menuliskan langkah merefleksi hasil yang diperoleh pada lembar jawab.

Seperti responden PA1, dua responden yang lain (PA2 dan PA3) telah memahami permasalahan pada soal nomor 1 dengan menuliskan informasi penting yang ada pada soal dengan benar. Informasi penting digunakan untuk menyusun strategi dengan menuliskan rumus yang akan digunakan dalam penyelesaian masalah. Rumus-rumus yang dituliskan PA2 adalah keliling alas, volume menara, volume prisma, volume limas, dan luas alas. Tahapan ketiga yaitu mengaplikasikan strategi, PA2 terlebih dahulu menghitung tinggi limas dengan cara mencari selisih antara tinggi menara dengan tinggi prisma. Lalu mencari panjang dan lebar alas menara (persegi panjang) menggunakan nilai keliling yang telah diketahui. Luas alas ditentukan terlebih dahulu sebelum menghitung volume prisma dan limas. Kemudian, untuk mencari volume menara PA2 menjumlahkan antara volume prisma dan volume limas. Langkah terakhir, PA2 merefleksi hasil yang diperoleh dengan cara menghitung ulang volume limas dan volume prisma. Pada saat wawancara, PA2 tidak mengalami kesulitan dalam menjawab setiap pertanyaan yang diajukan. PA2 juga menjelaskan langkah-langkah pengerjaan secara rinci sesuai dengan hasil tes kemampuan pemecahan masalah. Meskipun ketika wawancara, PA2 mengatakan sempat mengalami kesulitan dalam memahami soal-soal yang ada.

Sedangkan responden PA3 pada tahap mengaplikasikan strategi, diawali dengan mencari panjang dan lebar alas menara. Proses pengerjaan responden kurang terstruktur dan penggunaan simbol yang tidak konsisten. Sebagai contoh pada penulisan simbol lebar yang tidak konsisten. Responden menghitung tinggi limas dengan mencari selisih antara tinggi menara dan tinggi prisma. Setelah itu PA3 menghitung volume menara dengan menjumlahkan volume prisma dan volume limas. Langkah terakhir dalam memecahkan masalah adalah merefleksi hasil yang diperoleh. Namun, pada soal nomor 1 responden melewati langkah 
tersebut. Satuan volume yang ditulis oleh responden juga tidak konsisten.

Responden tidak menuliskan langkah keempat pada lembar jawab seperti pada Gambar 3. Hal tersebut diperkuat dengan hasil wawancara, bahwa langkah memeriksa kembali tidak dilakukan, karena sudah yakin atas jawaban yang diberikan. Pada saat wawancara, responden mengatakan bahwa sempat mengalami kesulitan ketika menghitung volume menara.

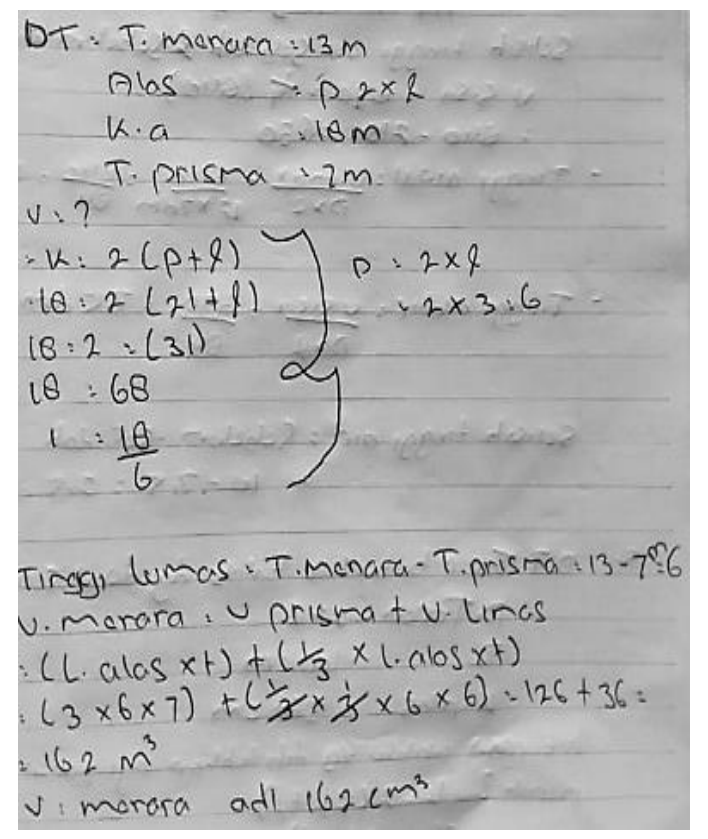

Gambar 3. Jawaban Responden PA3

\section{Deskripsi kemampuan pemecahan masalah matematis responden laki-laki untuk soal nomor 2}

Pada soal nomor 2, dengan menggunakan langkah-langkah penyelesaian masalah, responden diminta untuk menentukan selisih air bak mandi sebelum dan sesudah digunakan dengan diketahui panjang dan lebar bagian dalam berturut-turut adalah $1,2 \mathrm{~m}$ dan $0,7 \mathrm{~m}$, volume air maksimal 840 liter, bak mandi terisi penuh dan sesudah digunakan airnya berkurang $\frac{1}{4}$ dari volume awal. Seperti pada persoalan nomor 1, ketiga responden sudah dapat menuliskan menuliskan informasi penting dan menuliskan rumus-rumus yang akan digunakan dengan benar. Dengan kata lain ketiga responden sudah dapat memahami masalah dengan tepat. Pada langkah mengaplikasikan strategi, PA1 dan PA2 menghitung tinggi awal dan tinggi akhir menggunakan rumus volume. Setelah diperoleh tinggi awal dan tinggi akhir, PA1 menghitung selisih tinggi air tersebut. Langkah selanjutnya adalah merefleksikan hasil yang diperoleh. Namun, PA1 tidak menuliskan bagaimana proses memeriksa kembali jawabannya. Sedangkan PA 2 merefleksi hasil yang diperoleh dengan menghitung kembali volume akhir dan volume air yang digunakan.

Responden PA3 pada tahap mengaplikasikan strategi diawali dengan menghitung tinggi awal menggunakan volume maksimal, setelah itu menghitung tinggi akhir menggunakan volume sisa. Tinggi awal dan tinggi akhirdigunakan untuk menghitung selisih dari keduanya. Setelah PA3 memperoleh jawaban yang diinginkan, PA3 tidak menuliskan proses mengecek kembali jawaban yang diperoleh. Responden PA3 melewatkan 1 tahapan pemecahan masalah yaitu merefleksi hasil yang diperoleh. Pada saat wawancara, PA3 mengatakan tidak memeriksa kembali jawaban yang dituliskan. Hal tersebut dilakukan karena PA3 sudah merasa yakin dengan jawabannya. Siswa laki-laki cenderung lebih percaya diri terhadap pekerjaan matematika yang dilakukan (Espinoza $\&$ Taut, 2020).

\section{Deskripsi kemampuan pemecahan masalah matematis responden perempuan untuk soal nomor 1}

Responden PI1 dapat menuliskan informasi penting pada soal dan unsur 
yang ditanyakan dengan benar. PI1 menuliskan rumus yang digunakan untuk menyelesaikan soal dengan benar. Pada tahap mengaplikasikan strategi, PI1 langsung menghitung volume prisma dan volume limas, karena pada tahap sebelumnya telah menghitung panjang dan lebar alas menara. Setelah diperoleh volume prisma dan limas, PI1 menghitung volume menara dengan menjumlahkan keduanya. PI1 melakukan refleksi dengan cara menghitung ulang keliling menara berdasarkan panjang dan lebar yang telah dicari sebelumnya. Dengan demikian PI1 telah mampu menjawab soal nomor 1 sesuai dengan tahapan pemecahan masalah secara urut, lengkap dan benar. Hal tersebut didukung dengan hasil wawancara, dimana responden tanpa kesulitan dapat memberikan jawaban sesuai dengan jawaban yang dituliskan pada lembar jawab.

Seperti pada PI1, responden perempuan 2 (PI2) dapat menuliskan informasi penting yang diketahui, ditanyakan, dan rumus-rumus yang akan digunakan untuk menyelesaikan masalah. Tahap ketiga yaitu mengaplikasikan strategi, PI2 langsung menghitung volume prisma dan limas karena sudah menghitung panjang dan lebar alas pada tahap sebelumnya. Setelah diperoleh volume prisma dan limas, PI2 menjumlahkan keduanya. Selanjutnya pada tahap terakhir yaitu merefleksi hasil yang diperoleh, PI2 menghitung kembali volume prisma dengan mencari selisih antara volume menara dan limas. PI2 mampu mengerjakan soal nomor 1 sesuai dengan tahapan pada pemecahan masalah. Hasil wawancara menunjukan bahwa antara jawaban tes dan wawancara konsisten. Pada saat wawancara, PI2 mengatakan sempat mengalami kesulitan di langkah 4. Akan tetapi, dengan memahami dan meniru contoh pengerjaan langkah 4 pada contoh soal, PI2 dapat melakukan langkah 4 dengan benar.

Pada tahap memahami dan merencanakan strategi responden perempuan 3 (PI3) menuliskan informasi penting yang diketahui, unsur yang ditanyakan pada soal, dan menuliskan rumus yang digunakan dengan benar. PI3 menggambarkan sketsa dari menara yang terdiri dari gabungan prisma dan limas. Langkah ketiga yaitu: mengaplikasikan strategi, PI3 menghitung tinggi limas terlebih dahulu dengan mencari selisih antara tinggi menara dan tinggi prisma. PI3 menghitung lebar dan panjang alas menara menggunakan keliling alas yang sudah diketahui. Selanjutnya PI3 menghitung luas alas yang digunakan untuk menghitung volume prisma dan limas. Setelah diperoleh volume prisma dan volume limas, PI3 menghitung volume menara dengan menjumlahkan keduanya.

Langkah terakhir yaitu merefleksi hasil yang diperoleh, PI3 menghitung kembali volume prisma dan limas. Responden PI3 dapat menyelesaikan permasalahan dengan benar dan sesuai dengan langkah dalam pemecahan masalah. Hasil tersebut didukung oleh hasil wawancara, dimana PI3 mampu menjawab secara rinci setiap pertanyaan yang diajukan peneliti. PI3 juga mengatakan bahwa tidak menemukan kesulitan yang berarti saat mengerjakan soal nomor 1 .

\section{Deskripsi kemampuan pemecahan masalah matematis responden perempuan untuk soal nomor 2}

Untuk persoalan nomor 2, ketiga responden perempuan sudah dapat menuliskan informasi penting yang diketahui, unsur yang ditanyakan, dan 
DOI: https://doi.org/10.24127/ajpm.v10i2.3534

rumus yang digunakan untuk menyelesaikan persoalan dengan benar. Pada tahap menyusun strategi, PI1 terlebih dahulu mengubah satuan panjang dan lebar yang semula meter menjadi desimeter. PI1 menuliskan kembali volume air maksimum, dan menghitung volume sisa. Selanjutnya PI1 menuliskan rumus-rumus yang akan digunakan yaitu tinggi awal, tinggi akhir serta selisih tinggi. Selain itu, PI1 juga menghitung kembali volume sisa dengan mencari selisih antara volume awal dengan volume akhir.

Pada saat wawancara, PI1 menjelaskan setiap tahapan dengan tepat dan sesuai dengan jawaban yang ia tuliskan pada saat tes. Pada saat wawancara, PI1 mengatakan bahwa dipengerjaan pertama saat menghitung volume, ia memperoleh jawaban yang salah. Hal tersebut ia ketahui saat melakukan langkah keempat yaitu memeriksa kembali. Kemudian PI1 menghitung ulang dari awal sehingga ditemukan jawaban yang benar. Responden PI2 dalam tahap mengaplikasikan strategi, terlebih dahulu menghitung tinggi awal dan tinggi akhir menggunakan rumus yang telah dituliskan pada tahap sebelumnya. PI2 menghitung selisih antara tinggi awal dan tinggi akhir. Pada langkah keempat yaitu merefleksi hasil yang diperoleh, PI2 menghitung kembali volume air yang digunakan menggunakan selisih tinggi yang telah diperoleh sebelumnya. Selain itu, PI2 juga menghitung kembali volume sisa dengan mencari selisih antara volume maksimal dan volume air yang digunakan.

Gambar 4 menunjukkan bahwa PI2 telah menjawab soal nomor 4 dengan benar dan sesuai dengan tahapan pemecahan masalah. Hal tersebut diperkuat dengan hasil wawancara yang menunjukan bahwa PI2 mampu menjawab secara konsisten dan tepat. Meskipun saat diwawancara, PI2 menjelaskan bahwa ia sempat kesulitan memahami langkah keempat namun akhirnya ia mampu memahami.

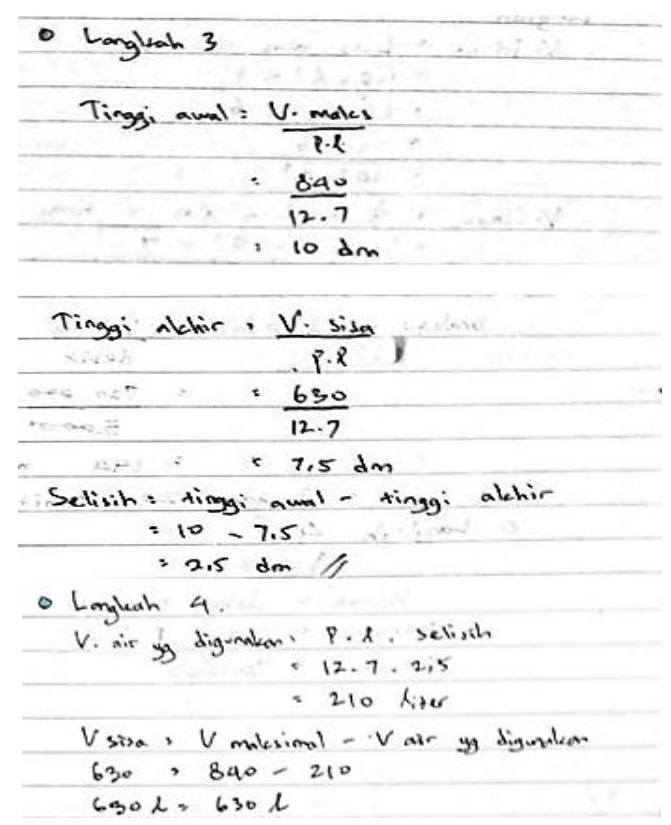

Gambar 4. Jawaban responden PI2 soal nomor 2

Sedangkan responden PI3 pada tahap menyusun strategi menuliskan kembali hal hal yang diketahui secara simbolis matematika. PI3 menghitung volume akhir menggunakan rumus volume maksimum dikurangi $1 / 4$ dari volume maksimum. Selain itu, PI3 juga menuliskan rumus-rumus yang akan digunakan pada nomor 2 yaitu rumus tinggi awal, tinggi akhir, serta selisih tinggi. Pada langkah mengaplikasikan strategi, PI3 terlebih dahulu menghitung tinggi awal kemudian menghitung tinggi akhir. Setelah diperoleh tinggi awal dan tinggi akhir, PI3 menghitung selisih keduanya. Terakhir pada tahap merefleksikan hasil yang diperoleh, PI3 menghitung kembali volume air yang digunakan menggunakan rumus panjang kali lebar kali selisih tinggi yang sebelumnya sudah diperoleh. Selain itu, 
DOI: https://doi.org/10.24127/ajpm.v10i2.3534

PI3 juga menghitung kembali volume akhir dengan mencari selisih antara volume maksimal dan volume air yang digunakan. Dengan demikian dapat dikatakan bahwa PI3 dapat mengerjakan soal nomor 2 dengan benar dan tepat dengan tahapan pemecahan masalah. Hal tersebut didukung hasil wawancara dimana PI3 mampu menjelaskan kembali proses pengerjaan soal tersebut. PI3 juga menjelaskan bahwa tidak menjumpai kendala yang berarti dalam mengerjakan soal nomor 2. Hasil deskripsi di atas secara sederhana disajikan dalam Tabel 1.

Tabel 1. Kemampuan pemecahan masalah matematis responden laki-laki dan perempuan

\begin{tabular}{|c|c|c|}
\hline Indikator & Laki-laki & Perempuan \\
\hline $\begin{array}{l}\text { Memahami masalah } \\
\text { yang diberikan }\end{array}$ & $\begin{array}{l}\text { Menuliskan informasi } \\
\text { penting dan unsur yang } \\
\text { ditanyakan dengan benar }\end{array}$ & $\begin{array}{l}\text { Menuliskan informasi penting } \\
\text { dan unsur yang ditanyakan } \\
\text { dengan benar }\end{array}$ \\
\hline $\begin{array}{l}\text { Menyusun strategi } \\
\text { untuk memecahkan } \\
\text { masalah }\end{array}$ & $\begin{array}{lr}\begin{array}{l}\text { Menuliskan rumus } \\
\text { digunakan }\end{array} \\
\text { menyelesaikan } & \text { permasalahan. } \\
\text { dalam }\end{array}$ & $\begin{array}{l}\text { Menuliskan rumus yang } \\
\text { digunakan dalam menyelesaikan } \\
\text { permasalahan }\end{array}$ \\
\hline $\begin{array}{l}\text { Mengaplikasikan } \\
\text { strategi untuk } \\
\text { menyelesaikan } \\
\text { masalah }\end{array}$ & $\begin{array}{l}\text { Mengaplikasikan rumus yang } \\
\text { telah dituliskan sebelumnya, } \\
\text { berdasarkan informasi } \\
\text { penting yang telah diketahui. }\end{array}$ & $\begin{array}{l}\text { Mengaplikasikan rumus yang } \\
\text { telah dituliskan sebelumnya, } \\
\text { berdasarkan informasi penting } \\
\text { yang telah diperoleh. }\end{array}$ \\
\hline $\begin{array}{l}\text { Merefleksi hasil } \\
\text { yang diperoleh }\end{array}$ & 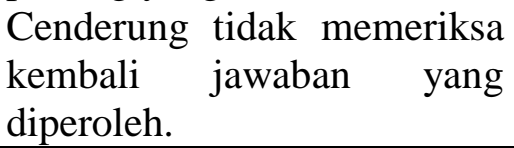 & $\begin{array}{l}\text { Memeriksa kembali jawaban } \\
\text { yang diperoleh. }\end{array}$ \\
\hline
\end{tabular}

Berdasarkan deskripsi dan Tabel 1, responden laki-laki mampu memahami soal dengan baik. Hal tersebut dibuktikan dengan kemampuan mereka pada saat menuliskan informasi penting yang diketahui. Siswa laki-laki menuliskan unsur-unsur tersebut secara singkat dan jelas. Meskipun mereka sempat menjumpai kendala saat memahami soal, namun pada akhirnya mereka mampu memahami dengan baik. Responden laki-laki juga mampu menuliskan unsur-unsur yang ditanyakan. Responden laki-laki mampu menyusun rencana cukup sistematis. Rencana yang disusun dengan menuliskan rumus-rumus yang akan digunakan untuk menyelesaikan permasalahan. Selanjutnya tahap mengaplikasikan strategi, dimana responden laki-laki menghitung unsur- unsur yang perlu dicari agar diperoleh hasil akhir yang diinginkan. Mereka memulai dari menghitung unsur yang belum diketahui pada soal hingga menghitung unsur yang ditanyakan. Sedangkan pada tahap merefleksi hasil yang diperoleh, responden laki-laki tidak menuliskan cara mereka dalam memeriksa kembali jawaban yang diperoleh. Responden laki-laki merasa tidak perlu melakukan pemeriksaan kembali karena sudah yakin dengan jawaban tersebut.

Begitu juga dengan responden perempuan sudah mampu memahami permasalahan dengan baik. Responden mampu dalam menuliskan unsur-unsur yang diketahui. Responden perempuan cenderung menuliskan secara detail mengenai informasi yang terdapat pada soal dan menuliskan unsur yang 
ditanyakan. Selain menggunakan bahasa yang jelas, responden perempuan memberikan keterangan bahwa telah menuliskan unsur yang ditanyakan pada soal. Pada tahap menyusun strategi, responden perempuan terlebih dahulu mencari unsur yang belum diketahui dalam soal. Selanjutnya menyusun rencana untuk menyelesaikan permasalahan. Rencana yang disusun yaitu menuliskan semua rumus yang dibutuhkan dalam soal tersebut.

Responden perempuan menuliskan rumus dengan lengkap dan menggunakan materi sebelumnya untuk menyelesaikan masalah. Pada tahap mengaplikasikan strategi, responden perempuan menghitung semua unsur yang dibutuhkan untuk mencapai hasil akhir. Pengerjaan dimulai dari menghitung unsur unsur dasar yang digunakan dalam rumus berikutnya. Misalnya ketika akan menghitung volume bangun gabungan, mereka terlebih dahulu menghitung volume dari masing-masing bangun. Responden perempuan sempat mengalami kesulitan saat mencapai langkah 4, namun tetap berusaha memahaminya. Setelah mencoba memahami, akhirnya responden perempuan dapat melewati langkah 4 dengan benar. Responden perempuan memeriksa kembali jawabannya dengan menghitung ulang beberapa unsur yang sudah diperoleh sebelumnya. Hal tersebut mereka lakukan untuk meminimalisir kesalahan atau ketidaktelitian saat mengerjakan soal. Pemeriksaan kembali terhadap jawaban yang diperoleh selalu dilakukan oleh responden perempuan. Kemampuan pemecahan masalah matematis responden perempuan sangat baik. Hal tersebut dibuktikan dengan responden perempuan mampu melakukan proses pemecahan masalah sampai tahap keempat. Mereka mampu menyelesaikan permasalahan dengan benar dan lengkap, serta mampu mengaplikasikan pengetahuan lama yang telah mereka peroleh untuk mengerjakan soal-soal yang disajikan.

Hasil tersebut menunjukkan bahwa terdapat perbedaan kemampuan pemecahan masalah matematis antara laki-laki dan perempuan. Masingmasing responden memiliki gaya penyelesaian masalah yang berbeda sesuai dengan kemampuan yang dimilikinya (Purwaningsih \& Ardani, 2020). Kemampuan pemecahan masalah matematis siswa perempuan dapat dikatakan lebih baik dari pada siswa laki-laki terutama pada tahap mengecek kembali. Hal ini sejalan dengan penelitian sebelumnya, dimana kemampuan pemecahan masalah siswa perempuan lebih baik dibandingkan dengan siswa laki-laki (Davita \& Pujiastuti, 2020; Hidayati et al., 2019). Mereka lebih rajin, ulet dan teliti (Kusumaningsih et al., 2018). Siswa perempuan mampu memanfaatkan peluang dan kompetensi yang dimilikinya (Borgonovi \& Greiff, 2020).

Diperlukan pembiasaan untuk mendorong kemampuan pemecahan masalah matematis siswa. Salah satu tahapan yang perlu dibiasakan adalah mengecek kembali terhadap solusi yang diberikan. Dengan mengecek kembali, maka akan mengurangi tingkat kesalahan yang dilakukan. Pembiasaan dapat dilakukan dengan pemberian permasalahan kontekstual. Pemberian masalah kontekstual menjadikan siswa berlatih mengenali, memahami informasi yang tersedia, dan memilih strategi pemecahan masalah yang tepat (Csíkos \& Szitányi, 2019). 
DOI: https://doi.org/10.24127/ajpm.v10i2.3534

\section{KESIMPULAN DAN SARAN}

Berdasarkan hasil dan pembahasan tentang kemampuan pemecahan masalah matematis berdasarkan gender, diperoleh kesimpulan bahwa responden laki-laki cenderung dapat menyelesaikan persoalan pemecahan masalah yang diberikan, hanya saja tidak melakukan refleksi kembali. Responden beranggapan bahwa jawaban yang mereka tuliskan sudah benar dan tidak perlu melakukan cek kembali. Sedangkan responden perempuan mampu mengerjakan soal menggunakan 4 tahap pemecahan masalah dengan benar. Dimana masing-masing responden mengerjakan setiap soal dengan detail dan penuh ketelitian. Tahap refleksi kembali selalu dilakukan oleh responden perempuan untuk menambah keyakinan, bahwa jawaban yang diberikan sudah benar dan memperbaikinya jika ada kesalahan. Penelitian ini baru sebatas ditinjau dari gender. Diduga kemampuan pemecahan masalah dipengaruhi oleh faktor-faktor yang lain, seperti kesiapan, kebiasaan, maupun emosional masing-masing individu. Untuk memperkuat hasil penelitian yang diperoleh, kedepannya perlu dilakukan pendalaman tentang faktor-faktor yang dapat mendukung kemampuan pemecahan masalah matematis siswa.

\section{DAFTAR PUSTAKA}

Ahdhianto, E., Marsigit, Haryanto, \& Nurfauzi, Y. (2020). Improving fifth-grade students' mathematical problem-solving and critical thinking skills using problembased learning. Universal Journal of Educational Research, 8(5), 2012-2021.

https://doi.org/10.13189/ujer.2020 .080539

Albay, E. M. (2019). Analyzing the effects of the problem solving approach to the performance and attitude of first year university students. Social Sciences \& Humanities Open, 1. https://doi.org/10.1016/j.ssaho.20 19.100006

Borgonovi, F., \& Greiff, S. (2020). Societal level gender inequalities amplify gender gaps in problem solving more than in academic disciplines. Intelligence, 79. https://doi.org/10.1016/j.intell.201 9.101422

Chen, S.-Y., \& Lin, S.-W. (2019). A Cross-Cultural Study of Mathematical Achievement: from the Perspectives of One's Motivation and Problem-solving Style. International Journal of Science and Mathematics Education. https://doi.org/10.1007/s10763019-10011-6

Csíkos, C., \& Szitányi, J. (2019). Teachers' pedagogical content knowledge in teaching word problem solving strategies. $Z D M$ Mathematics Education. https://doi.org/10.1007/s11858019-01115-y

Davita, P. W. C., \& Pujiastuti, H. (2020). Anallisis Kemampuan Pemecahan Masalah Matematika Ditinjau Dari Gender. Kreano, Jurnal Matematika KreatifInovatif, 11(1), 110-117. https://doi.org/10.15294/kreano.v 11 i1.23601

Espinoza, A. M., \& Taut, S. (2020). Gender and Psychological Variables as Key Factors in Mathematics Learning: A Study of Seventh Graders in Chile. International Journal of Educational Research, 103. https://doi.org/10.1016/j.ijer.2020. 101611 
García, T., Boom, J., Kroesbergen, E. H., Núñez, J. C., \& Rodríguez, C. (2019). Planning, execution, and revision in mathematics problem solving: Does the order of the phases matter? Studies in Educational Evaluation, 61, 8393.

https://doi.org/10.1016/j.stueduc.2 019.03.001

Giofrè, D., Cornoldi, C., Martini, A., \& Toffalini, E. (2020). A population level analysis of the gender gap in mathematics: Results on over 13 million children using the INVALSI dataset. Intelligence, 81.

https://doi.org/10.1016/j.intell.202 0.101467

Hidayati, Y., Rosidi, I., \& Hadi, W. P. (2019). The Identification Problem-Solving Abilities Based on Gender: Implementation Teaching Science Trough Guided Discovery Model's in Bangkalan District. Journal of Physics: Conference Series, 1227. https://doi.org/10.1088/17426596/1227/1/012039

Hobri, Ummah, I. K., Yuliati, N., \& Dafik. (2020). The effect of jumping task based on creative problem solving on students' problem solving ability. International Journal of Instruction, 13(1), 387-406. https://doi.org/10.29333/iji.2020.1 $3126 \mathrm{a}$

Jamaludin, A., \& Hung, D. (2017). Problem-solving for STEM learning: navigating games as narrativized problem spaces for 21 st century competencies. Research and Practice in Technology Enhanced Learning, 12(1), $1-14$. https://doi.org/10.1186/s41039-
016-0038-0

Khalid, M., Saad, S., Abdul Hamid, S. R., Ridhuan Abdullah, M., Ibrahim, H., \& Shahrill, M. (2020). Enhancing creativity and problem solving skills through creative problem solving in teaching mathematics. Creativity Studies, 13(2), 270-291. https://doi.org/10.3846/cs.2020.11 027

Kusumaningsih, W., Darhim, Herman, T., \& Turmudi. (2018). Gender differences in algebraic thinking ability to solve mathematics problems. Journal of Physics: Conference Series, 1013. https://doi.org/10.1088/17426596/1013/1/012143

Mefoh, P. C., Nwoke, M. B., Chukwuorji, J. B. C., \& Chijioke, A. O. (2017). Effect of cognitive style and gender on adolescents' problem solving ability. Thinking Skills and Creativity, 25, 47-52. https://doi.org/10.1016/j.tsc.2017. 03.002

Nanna, A. W. I., \& Pratiwi, E. (2020). Students' Cognitive Barrier in Problem Solving: Picture-based Problem-solving. Al-Jabar: Jurnal Pendidikan Matematika, 11(1), 73-82. https://doi.org/10.24042/ajpm.v11 i1.5652

Purwaningsih, D., \& Ardani, A. (2020). Kemampuan Pemecahan Masalah Matematis Materi Eksponen Dan Logaritma Ditinjau Dari Gaya Belajar Dan Perbedaan Gender. AKSIOMA: Jurnal Program Studi Pendidikan Matematika, 9(1), 118. https://doi.org/10.24127/ajpm.v9i 1.2632

Ramdan, Z. M., Veralita, L., Rohaeti, E. E., \& Purwasih, R. (2018). 
DOI: https://doi.org/10.24127/ajpm.v10i2.3534

Analisis Self Confidence

Terhadap Kemampuan

Pemecahan Masalah Matematis

Siswa SMK Pada Materi Barisan

dan Deret. AKSIOMA: Jurnal

Program Studi Pendidikan

Matematika, $\quad 7(2), \quad 171$. https://doi.org/10.24127/ajpm.v7i

2.1335

Rott, B. (2019). Teachers' Behaviors, Epistemological Beliefs, and Their Interplay in Lessons on the Topic of Problem Solving. International Journal of Science and Mathematics Education. https://doi.org/10.1007/s10763019-09993-0

Surya, E., Putri, F. A., \& Mukhtar. (2017). Improving mathematical problem-solving ability and selfconfidence of high school students through contextual learning model. Journal on Mathematics Education, 8(1), 8594.

https://doi.org/10.22342/jme.8.1.3 324.85-94

Yandari, I. A. V., Supartini, S., Pamungkas, A. S., \& Khaerunnisa, E. (2019). The Role of Habits of Mind (HOM) on Student's Mathematical Problem Solving Skills of Primary School. Al-Jabar: Jurnal Pendidikan Matematika, 10(1), 47-57. https://doi.org/10.24042/ajpm.v10 i1. 4018

Zhou, D., Du, X., Hau, K. T., Luo, H., Feng, P., \& Liu, J. (2019). Teacher-student relationship and mathematical problem-solving ability: mediating roles of selfefficacy and mathematical anxiety. Educational Psychology. https://doi.org/10.1080/01443410. 2019.1696947 